\title{
Effect of Heavy Metals on Oxidative Stress Parameters of Cattle Inhabiting Buddha Nallah Area of Ludhiana District in Punjab
}

\section{Dhaliwal RS and Chhabra Sushma*}

Department of Veterinary Medicine, College of Veterinary Science, GADVASU, Ludhiana, Punjab, India

\begin{abstract}
In the present study, heavy metals' $(\mathrm{Pb}, \mathrm{Cd}, \mathrm{As}, \mathrm{Ni})$ status and their effect on oxidative stress parameters in cattle inhabiting Buddha Nallah was assessed. A total of 63 cows were randomly selected for the study and blood plasma samples were obtained from the animals and analyzed for heavy metals and for various oxidative stress parameters viz., GSH (Reduced glutathione), malonyldialdehyde (MDA) and superoxide dismutase (SOD). A significant $(p<0.01)$ increase in plasma heavy metals was recorded in the cows. A significant decrease in GSH $(p<0.01)$ and SOD $(p<0.05)$ and significant increase $(p<0.01)$ in MDA levels was indicative of oxidative damage which may lead to detrimental health hazards in the animals inhabiting Buddha Nallah area of Ludhiana district.
\end{abstract}

Keywords: Cows; Heavy metals; Oxidative stress; Plasma

\section{Introduction}

The continued modernization, development and industrialization of district Ludhiana of Punjab have led to extensive environmental problems [1]. The diverse deleterious health effect upon exposure to toxic heavy metals in the environment is a matter of serious concern and global issue. The anthropogenic activities and vehicular emissions contribute to the entry of toxic metals to humans and other animal's food chains [2]. Heavy metals induce tissue damage by oxidative stress pathway. Long-term exposure to heavy metals increases lipid peroxidation and inhibition of SOD activity indicating oxidative damage [3].

Buddha Nallah, a narrow unlined canal, is the Ludhiana city's sole surface water resource. It originates from Chamkaur Sahib town and merges in the river Sutlej. It is an important drainage line of Ludhiana district which passes through Ludhiana and carries the sewage and industrial sludge of the city. Purpose of the study was to estimate heavy metal status of the cattle inhabiting Buddha Nallah area of Ludhiana district in Punjab and to study its effect on oxidative stress parameters in cattle.

\section{Materials and Methods}

\section{Collection of samples}

A total of 63 crossbred cattle, aged 4-7 years were randomly selected from 10 villages of Buddha Nallah area. Blood samples from these cattle were collected randomly in sterile test tubes containing anticoagulant (heparin). The samples were centrifuged at $3000 \mathrm{rpm}$ for 30 minutes at room temperature to separate plasma. The plasma samples were stored in small aliquots in mineral free glass vials at $-10^{\circ} \mathrm{C}$ until analysis. Two millilitres of plasma was digested with nitric acid and perchloric acid and after digestion the volume was made up to $10 \mathrm{ml}$ with double distilled water for heavy metal analysis by Atomic Absorption Spectrophotometer (Perkin Elmer Analyst 700, USA).

Control animals $(n=20)$ were selected from area which was far away from Buddha Nallah area, which was supposed to be not exposed to pollution of Buddha Nallah.

\section{Preparation of 10 percent $\mathrm{RBC}$ haemolysate and analysis of} GSH, MDA and SOD

Freshly collected blood samples were centrifuged at $2000 \mathrm{rpm}$ for 10 minutes and the supernatant was discarded. The sedimented cells were washed with 0.9 percent $\mathrm{NaCl}$ solution. The process was repeated three times. Washed erythrocytes were haemolysed with 9-fold volume of distilled water to prepare 10 percent RBC haemolysate. The haemolysate was used to analyze reduced glutathione, malonyldialdehyde and superoxide dismutase.

The level of erythrocyte reduced glutathione was assayed [4]. This method is based on the capacity of sulphhydryl groups present in whole blood react with DNTB and form a yellow dye, with maximum absorbance at $412 \mathrm{~nm}$. Estimation of product of lipid peroxidation i.e., malonyldialdehyde in erythrocytes was assayed by the method described based upon the reaction of thiobarbituric acid (TBA) with MDA [5].

The activities of superoxide dismutase in erythrocytes were measured by the method [6]. The assay is based on the principle that the nitrobluetetrazolium (NBT) inhibits superoxide dismutase with reduced nicotinamide adenine dinucleotide (NADH) mediated by phenazonium methosulphate (PMS) under aerobic conditions.

\section{Results and Discussion}

The mean levels of heavy metals viz., $\mathrm{Pb}, \mathrm{Cd}, \mathrm{Ni}$ and $\mathrm{As}$ in cattle were above the normal limits given [7]. The levels were also significantly $(p<0.01)$ higher than the mean heavy metals concentration of control animals (Table 1). Higher levels (0.883-1.539 ppm) of $\mathrm{Pb}$ were also observed by in jersey cows along with higher levels of cadmium after 4 weeks of exposure to fodder irrigated with sewage water [8]. Blood cadmium levels are indicative of recent exposure to cadmium but are not especially indicative of total body burden [9]. Results similar to present study were also observed in cow blood from cows grazed around Zango, Zaria and Challawa industrial estate, Kano Nigeria and found that 0.04-5.05 ppm of nickel [10].

*Corresponding author: Sushma Chhabra, Department of Veterinary Medicine, College of Veterinary Science, GADVASU, Ludhiana-141 004, Punjab, India, Tel: +919463005061; E-mail: chhabrasushma@rediffmail.com

Received March 25, 2016; Accepted June 20, 2016; Published June 24, 2016

Citation: Dhaliwal RS, Sushma C (2016) Effect of Heavy Metals on Oxidative Stress Parameters of Cattle Inhabiting Buddha Nallah Area of Ludhiana District in Punjab. J Vet Sci Technol 7: 352. doi:10.4172/2157-7579.1000352

Copyright: (c) 2016 Dhaliwal RS, et al. This is an open-access article distributed under the terms of the Creative Commons Attribution License, which permits unrestricted use, distribution, and reproduction in any medium, provided the original author and source are credited. 
The overall mean value of GSH in erythrocytes of cattle was $0.86 \pm 0.11$ $\mathrm{mM}$ which was significantly $(\mathrm{p}<0.01)$ lower than the mean control value $(1.41 \pm 0.22 \mathrm{mM})$. The GSH in erythrocytes of cattle inhabiting Buddha Nallah area ranged from $0.79 \pm 0.05 \mathrm{mM}$ to $0.96 \pm 0.19 \mathrm{mM}$ (Table 2).

Levels of GSH decreased due to multifactorial pathogenicity [11]. Heavy metals directly interrupted the activity of enzymes and deactivated antioxidant sulfhydryl pools. Many researchers have demonstrated that GSH was decreased in rats chronically exposed to lead [12-14]. Arsenic exposure results in decreased GSH levels and lipid peroxidation in rats [15]. GSH acts as an electron donor for the reduction of arsenicals and arsenicals had high affinity to GSH. Various researchers observed a direct correlation between lead concentration and lipid peroxidation $[16,17]$.

The overall mean value of MDA in cattle was $491.11 \pm 113 \mathrm{nmol} / \mathrm{g}$ $\mathrm{Hb}$ which was significantly $(\mathrm{p}<0.01)$ higher than the mean control value $(414.4 \pm 70.2 \mathrm{nmol} / \mathrm{g} \mathrm{Hb})$. The MDA values of cattle of different zones of Buddha Nallah ranged from $433.0 \pm 85 \mathrm{nmol} / \mathrm{g} \mathrm{Hb}$ to 533.02 $\pm 142.8 \mathrm{nmol} / \mathrm{g} \mathrm{Hb}$.

MDA (Malodialdehyde) was a well-known lipid peroxidation indicator after Cd exposure [18]. Cd exposure disturbed GSH and metallothionein levels and may allow free radicals to attack double bonds in membrane lipids and result in an increase in lipid peroxidation.

According to a study, the average MDA level of the cattle which were living near the trunk roads was increased about three times than control [19]. In that study mean blood levels were significantly correlated with MDA levels. $\mathrm{Pb}$ accumulation was affected the lipid peroxidation, which result in increased levels of MDA.

Increased lipid peroxidation was observed in tissues of nickel chloride-treated rats [20,21]. Lipid peroxidation was measured by the thiobarbituric acid reaction for malondialdehyde (MDA) and related chromogens in fresh tissue homogenates. They also observed dose effect relation for lipid peroxidation in liver and kidney.

The overall mean value of SOD in cattle $(16.33 \pm 2.54 \mathrm{U} / \mathrm{mg}$ of $\mathrm{Hb})$ was significantly $(\mathrm{p}<0.05)$ lower than the mean control value $(23.31 \pm 3.97 \mathrm{U} / \mathrm{mg}$ of $\mathrm{Hb})$ and it ranged from $12.93 \pm 1.19 \mathrm{U} / \mathrm{mg}$ of $\mathrm{Hb}$ to $19.85 \pm 2.94 \mathrm{U} / \mathrm{mg}$ of $\mathrm{Hb}$. Similar results were reported by some workers $[22,23]$ which showed decreased RBC SOD activity in leadexposed rats and in white stork chicks in polluted area [24], whereas a study indicated that erythrocyte $\mathrm{Cu} / \mathrm{Zn}$-SOD activities were reduced

\begin{tabular}{|c|c|c|c|}
\hline Parameter & Control & Cattle $(\mathbf{n}=63)$ & Normal limits (by Puls) \\
\hline $\mathbf{P b}(\mathbf{p p m})$ & $0.11 \pm 0.02$ & $0.58 \pm 0.06^{* *}$ & $0.1-0.2$ \\
\hline $\mathbf{C d}(\mathbf{p p m})$ & $0.05 \pm 0.01$ & $0.12 \pm 0.02^{* *}$ & $0.001-0.04$ \\
\hline $\mathbf{N i}(\mathbf{p p m})$ & $0.008 \pm 0.002$ & $0.04 \pm 0.006^{* *}$ & $0.001-0.006$ \\
\hline As (ppm) & $0.05 \pm 0.01$ & $0.13 \pm 0.02^{*}$ & $0.003-0.05$ \\
\hline
\end{tabular}

*Significant difference $(P<0.05)$ with control group

"Significant difference $(P<0.01)$ with control group

Table 1: Levels of heavy metals in plasma samples of cattle inhabiting Buddha Nallah area of district Ludhiana, Punjab (Mean \pm S.E).

\begin{tabular}{|c|c|c|}
\hline Parameters & Control & Overall $(\mathbf{n}=\mathbf{6 3})$ \\
\hline GSH (mM) & $1.41 \pm 0.22$ & $0.86 \pm 0.11^{* *}$ \\
\hline MDA (nmol/g Hb) & $414.4 \pm 70.2$ & $491.11 \pm 113^{* *}$ \\
\hline SOD (U/mg Hb) & $23.31 \pm 3.97$ & $16.33 \pm 2.54^{*}$ \\
\hline
\end{tabular}

'Significant difference $(P<0.05)$ with control group "Significant difference $(P<0.01)$ with control group

Table 2: Oxidative stress parameters of cattle inhabiting Buddha Nallah area of District Ludhiana, Punjab (Mean \pm S.E). in humans as a result of long-term Cd exposure in Cd-polluted areas [25]. SOD required copper and zinc for its activity. Copper ions played functional role in the reaction by undergoing alternate oxidation whereas zinc ions seem to stabilize the enzyme. Both the metal ions were replaced by lead which decreased the activity of SOD [26].

According to a study, cadmium binds to imidazole group of SOD which is vital for breakdown of hydrogen peroxide [27]. The reduced effectiveness of SOD enzyme was probably due to the substitution of cadmium for manganese.

\section{Conclusion}

Significant decrease in GSH $(\mathrm{p}<0.01)$ and $\operatorname{SOD}(\mathrm{p}<0.05)$ and significant increase $(p<0.01)$ in MDA levels in the cows with higher concentrations of heavy metals were indicative of oxidative damage. It may lead to detrimental health hazards in the animals inhabiting Buddha Nallah area of Ludhiana District of Punjab.

\section{References}

1. Singla R (2011) Built Environment in Ludhiana: Issues and Options. Institute of Town Planners, India Journal 8: 90-95.

2. Okada IA, Sakuma AM, Maio FD, Dovidauskas S, Zenebon O (1997) Evaluation of lead and cadmium levels in milk in environmental contamination in the Vale do Paraíba Region, southeastern Brazil. Rev Saude Publica 31: 140-143.

3. Patra RC, Swarup D, Senapati SK (1999) Effects of cadmium on lipid peroxides and superoxide dismutase in hepatic, renal and testicular tissue of rats. Vet Hum Toxicol 41: 65-67.

4. Beutle RE, Duron O, Kelly BM (1963) Improved method for the determination of blood glutathione. J Lab Clin Med 61: 882-888.

5. Placer ZA, Cushman LL, Johnson BC (1966) Estimation of product of lipid peroxidation (malonyl dialdehyde) in biochemical systems. Anal Biochem 16 359-364.

6. Nishikimi M, Appaji N, Yagi K (1972) The occurrence of superoxide anion in the reaction of reduced phenazine methosulfate and molecular oxygen. Biochem Biophys Res Commun 46: 849-854.

7. Puls R (1994) Mineral Levels in Animal Health. Diagnostic Data. 2nd edn Sherpa International, Clearbrook, BC, Canada.

8. Somasundaram J, Krishnasamy R, Savithri P (2005) Biotransfer of heavy metals in Jersey cows. Indian J Anim Sci 75: 1257-1260.

9. Agency for Toxic Substances and Disease Registry (2012) Toxicological Profile for Cadmium. US Department of Health and Human Services.

10. Ogabiela EE, Yebpella GG, Adesina OB, Udiba UU, Ade-Ajayi FA, et al. (2011) Assessment of metals levels in cow blood from cow's grazed around Zango, Zaria and Challawa industrial estate, Kano-Nigeria. J Appl Environ Biol Sci 1: 69-73.

11. Patrick $L$ (2006) Lead toxicity part II: the role of free radical damage and the use of antioxidants in the pathology and treatment of lead toxicity. Altern Med Rev 11: 114-127.

12. Gurer $\mathrm{H}$, Ercal $\mathrm{N}(2000)$ Can antioxidants be beneficial in the treatment of lead poisoning? Free Radic Biol Med 29: 927-945.

13. Christie NT, Costa M (1984) In vitro assessment of the toxicity of metal compounds IV. Disposition of metals in cells: interaction with membranes, glutathione, metallothionein and DNA. Biol Trace Elem Res 6: 139-158.

14. Monteiro HP, Abdalla DS, Arcuri AS, Bechara EJ (1985) Oxygen toxicity related to exposure to lead. Clin Chem 31: 1673-1676.

15. Ramos O, Carrizales L, Yáñez L, Mejía J, Batres L, et al. (1995) Arsenic increased lipid peroxidation in rat tissues by a mechanism independent of glutathione levels. Environ Health Perspect 103 Suppl 1: 85-88.

16. Shafiq-ur-Rehman, Rehman S, Chandra O, Abdulla M (1995) Evaluation of malondialdehyde as an index of lead damage in rat brain homogenates. Biometals 8: 275-279.

17. Sandhir R, Gill KD (1995) Effect of lead on lipid peroxidation in liver of rats. Biol Trace Elem Res 48: 91-97. 
Citation: Dhaliwal RS, Sushma C (2016) Effect of Heavy Metals on Oxidative Stress Parameters of Cattle Inhabiting Buddha Nallah Area of Ludhiana District in Punjab. J Vet Sci Technol 7: 352. doi:10.4172/2157-7579.1000352

18. Shaikh ZA, Vu TT, Zaman K (1999) Oxidative stress as a mechanism of chronic cadmium-induced hepatotoxicity and renal toxicity and protection by antioxidants. Toxicol Appl Pharmacol 154: 256-263.

19. Arslan HH, Aksu DS, Ozdemir S, Yavuz O, Erman ORM, et al. (2011) Evaluation of the relationship of blood heavy metal, trace element levels and antioxidative metabolism in cattle which are living near the trunk roads. Kafkasuniversitesi metabolism in cattle which are living
Veteriner Fakultesi Dergisi 17: S77.

20. Sunderman FW Jr, Marzouk A, Hopfer SM, Zaharia O, Reid MC (1985) Increased lipid peroxidation in tissues of nickel chloride-treated rats. Ann Clin Lab Sci 15: 229-236.

21. Misra M, Rodriguez RE, Kasprzak KS (1990) Nickel induced lipid peroxidation in rat: correlation with nickel effect on antioxidant defense systems. Toxicology 64: $1-17$

22. Adler AJ, Barth RH, Berlyne GM (1993) Effect of lead on oxygen free radical metabolism: Inhibition of superoxide dismutase activity. Trace elements in medicine 10: 93-96.
23. Ariza ME, Bijur GN, Williams MV (1998) Lead and mercury mutagenesis: role of $\mathrm{H}_{2} \mathrm{O}_{2}$, superoxide dismutase, and xanthine oxidase. Environ Mol Mutagen 31: $352-361$

24. Kaminski P, Kurhalyuk N, Szady-Grad M (2007) Heavy metal-induced oxidative stress and changes in physiological process of free radicals in blood of white strok (Ciconiaciconia) chicks in polluted areas. Polish $\mathrm{J}$ of Environ Stud 16: 555-562.

25. Uchida M, Teranishi H, Aoshima K, Katoh T, Kasuya M, et al. (2004) Reduction of erythrocyte catalase and superoxide dismutase activities in male inhabitants of a cadmium-polluted area in Jinzu river basin, Japan. Toxicol Lett 151: 451-457.

26. Halliwell B, Gutteridge JMC (1989) Free radicals in biology and medicine. 2nd edn. Oxford Clarendon Press, New York, USA.

27. Casalino E, Calzaretti G, Sblano C, Landriscina C (2002) Molecular inhibitory mechanisms of antioxidant enzymes in rat liver and kidney by cadmium. Toxicology 179: 37-50 